\title{
Hubungan Ketersediaan Sanitasi Dasar terhadap Status Gizi Baduta di Desa Pelem, Bojonegoro
}

\author{
Qonita Basyariyah $^{1}$, Khuliyah Candraning Diyanah ${ }^{2 *}$, Aditya Sukma Pawitra ${ }^{2}$ \\ 1 Peminatan Kesehatan Lingkungan, Program Studi Kesehatan Masyarakat, Fakultas Kesehatan Masyarakat Universitas \\ Airlangga, Surabaya 60115, Indonesia \\ 2 Departemen Kesehatan Lingkungan, Fakultas Kesehatan Masyarakat Universitas Airlangga, Surabaya 60115, Indonesia \\ *Corresponding author: k.c.diyanah@fkm.unair.ac.id
}

Info Artikel:Diterima 30 Juni 2021 ; Direvisi 8 Desember 2021 ; Disetujui 19 Desember 2021

Tersedia online : 2 Februari 2022 ; Diterbitkan secara teratur : Februari 2022

Cara sitasi (Vancouver): Basyariyah Q, Diyanah KC, Pawitra AS. Hubungan Ketersediaan Sanitasi Dasar terhadap Status Gizi Baduta di Desa Pelem, Bojonegoro. Jurnal Kesehatan Lingkungan Indonesia [Online]. 2022 Feb;21(1):18-26. https://doi.org/10.14710/jkli.21.1.18-26.

\begin{abstract}
ABSTRAK
Latar belakang: Sanitasi lingkungan dasar merupakan salah satu faktor yang mempengaruhi status gizi baduta. Berdasarkan data dari Puskesmas Purwosari sebanyak 11 baduta memiliki status gizi kurang dan 8 diantaranya berasal dari Desa Pelem. Penelitian ini bertujuan untuk menganalisis hubungan ketersediaan sanitasi dasar dengan status gizi pada baduta di Desa Pelem, Bojonegoro.

Metode: Penelitian ini merupakan penelitian observasional dengan rancangan cross sectional. Lokasi penelitian di Desa Pelem, Kecamatan Purwosari, Kabupaten Bojonegoro yang dilaksanakan pada tanggal 28 Desember 2019 - 14 Januari 2020. Sampel pada penelitian ini yaitu total dari populasi seluruh baduta sebanyak 51 anak. Variabel yang diteliti yaitu status gizi baduta, sumber air bersih, ketersediaan jamban sehat, dan kepemilikan SPAL. Data diperoleh dari hasil observasi dan wawancara yang kemudian dianalisis menggunakan uji chisquare.

Hasil: Mayoritas masyarakat Desa Pelem mengambil sumber air bersih yang berasal dari sumur (94,0\%), rumah yang telah memiliki jamban sehat hanya $60,7 \%$ dan $58,8 \%$ belum memiliki SPAL. Hasil analisis menunjukkan ketersediaan jamban sehat $(\mathrm{p}=0,004<\alpha)$ dan kepemilikan SPAL $(\mathrm{p}=0,015<\alpha)$ memiliki hubungan yang signifikan terhadap status gizi pada baduta.

Simpulan: Ada hubungan antara ketersediaan jamban sehat dan kepemilikan SPAL terhadap status gizi baduta, sehingga strategi terhadap ketersediaan jamban sehat dan SPAL perlu dilakukan untuk menurunkan risiko status gizi kurang pada baduta.
\end{abstract}

Kata kunci: Sumber air bersih; Jamban sehat; SPAL; Baduta; Status gizi

ABSTRACT

Title: Analysis Availability of Basic Sanitation On Nutritional Status Of Baduta In Pelem Village, Bojonegoro.

Background: Environmental basic sanitation is one of the factor affect the nutritional status of baduta. Based on data from Purwosari Health Center as many as 11 baduta have undernutrition status and 8 between them are from Pelem Village. Study aims to analyze availability of basic sanitation with nutritional status in underfives in Pelem Village, Bojonegoro.

Method: This research is an observational study with a cross sectional design. The research location was in Pelem Village, Purwosari District, Bojonegoro Regencyon 28 December 2019 - 14 January 2020. The sample in this study was the total population of all baduta with a total of 51 children. The variables studied are baduta 
nutritional status, availability of health latrines, and SPAL ownership. The data was obtained from observations and interviews then were analyzed using the chi-square test.

Result: The majority of the people in Pelem Village took clean water from wells (94.0\%), there were houses that have health latrine just $60,7 \%$ and about $58.8 \%$ did not have sewerage. Availability of healthy latrines $(p=0,004$ $<\alpha)$ and sewerage ownership $(p=0,015<\alpha)$ have a significant relationship with nutritional status in underfives.

Conclusion: There is a relationship between the availability healthy latrines and sewerage ownership on the nutritional status of under-five children.

Keywords: Clean water source; Healthy Latrines; Sewerage; Baduta; Nutritional Status

\section{PENDAHULUAN}

Status gizi sejak periode janin hingga anak berusia 2 tahun menjadi hal krusial di masa perkembangan dan pertumbuhan anak, seperti perkembangan kreativitas, emosional, kemampuan berbahasa, intelektual, dan lainnya. Kelahiran bayi hingga berusia 2 tahun sering disebut sebagai periode 1000 Hari Pertama Kehidupan (HPK) manusia. Periode 1000 HPK merupakan periode yang penting dan sensitif karena dampak yang ditumbulkan pada masa ini bersifat permanen dan sulit untuk diperbaiki ${ }^{1}$. Hal yang perlu diperhatikan saat selama 1000 HPK adalah asupan nutrisi, kebersihan peralatan makan, serta stimulasi dari lingkungan yang dapat membentuk hubungan antarsel saraf otak semakin kuat ${ }^{2}$.

Masa perkembangan dan pertumbuhan anak yang berusia kurang dari 2 tahun (baduta) menjadi kesempatan untuk mencapai kemampuan optimal anak. Faktor yang mempengaruhi status gizi ada dua, yaitu faktor langsung dan tidak langsung. Faktor langsung berupa kualitas dan kuantitas pangan yang dikonsumsi, serta penyakit infeksi. Faktor tidak langsung antara lain sanitasi lingkungan, sosial ekonomi, jarak kelahiran, dan pendapatan ${ }^{3}$. Baduta akan rentan terkena dampak negatif yang mempengaruhi kesehatan jika tidak diberikan nutrisi yang baik, pengasuhan yang benar, dan lingkungan yang sehat dan kondusif ${ }^{4}$. Hal tersebut dibuktikan oleh penelitian Simbolon (2017) dan Riski, dkk (2019) yang menyatakan bahwa hygiene sanitasi lingkungan berhubungan dengan status gizi anak ${ }^{5,6}$.

Anak yang memiliki asupan gizi yang baik dan berada di lingkungan yang sehat akan memiliki pertumbuhan fisik dan kognisi yang lebih sehat dikarenakan hal tersebut merupakan ruang lingkup dari kesejahteraan anak. Sarana sanitasi dasar pada rumah dapat meliputi ketersediaan jamban sehat, sarana air bersih, pengelolaan air limbah dan tempat sampah. Ramdaniati dan Nastiti (2019) mengemukakan bahwa sumber air bersih memiliki hubungan dengan kejadian stunting pada balita (pvalue $=0,011)$ karena air yang tidak layak akan menimbulkan berbagai penyakit ${ }^{7}$. Akses dan kepemilikan jamban sehat serta ketersediaan pembuangan air limbah yang layak memiliki hubungan terhadap kejadian stunting pada anak yang telah dibuktikan oleh penelitian Hasan, dkk (2019) dan Soerachmad, dkk (2019) $)^{8,9}$.

Sanitasi lingkungan yang buruk dan tidak sanitier akan menimbulkan keberadaan bakteri yang dapat menggunakan tubuh anak menjadi inang untuk tempat berkembang biak dan reproduksi dan memicu anak mengalami enteropati lingkungan, serta anak akan mengalami berbagai penyakit seperti diare, pneumonia, dan penyakit yang mempengaruhi gizi anak, yaitu malnutrisi, stunting, gizi kurang, hingga gizi buruk ${ }^{10}$. Menurut penelitian Kurniawan (2018) bahwa sanitasi lingkungan memiliki pengaruh terhadap status gizi balita (pvalue $=0,032$ ). Balita yang tumbuh di lingkungan tidak sehat berisiko satu kali lebih besar mengalami status gizi buruk ${ }^{6}$. Enteropati lingkungan merupakan sindrom yang menunjukkan adanya perubahan pada usus kecil akibat dari kontaminasi feses dalam jangka panjang dan kurangnya fasilitas sanitasi dasar ${ }^{11}$. Hal tersebut diakibatkan banyaknya jumlah bakteri tinja dalam tubuh akibat kontaminasi feses, sehingga akan membebani usus berlebihan hingga berdampak pada mukosa bocor, fungsi vili yang buruk, sel usus membengkak, malabsorpsi hingga menyebabkan kegagalan pertumbuhan linear ${ }^{12,13}$. Kekurangan gizi pada anak di bawah lima tahun mengakibatkan kematian pada $45 \%$ dari 5 juta kematian dan melibatkan 155 balita mengalami kegagalan pertumbuhan linear ${ }^{14-16}$. Peningkatan kualitas sanitasi lingkungan dan kebersihan rumah dapat mencegah anak mengalami permasalahan kesehatan berdasarkan penelitian Kamara, dkk (2017) ${ }^{17}$.

World Health Organization (WHO) melaporkan bahwa terdapat 178 juta anak di dunia mengalami kekurangan gizi dan 3,5 sampai 5 juta anak dibawah lima tahun mengalami kematian akibat gizi kurang ${ }^{18}$. Berdasarkan data UNICEF menunjukkan pada tahun 2012 diperkirakan 25\% atau 162 juta anak - anak diseluruh dunia mengalami malnutrisi, sedangkan di Indonesia terdapat $36 \%$ balita yang mengalami malnutrisi. Gizi kurang merupakan salah satu masalah gizi utama pada balita Indonesia. Indonesia berada pada peringkat ke delapan dengan angka tingkat kematian paling tinggi untuk anak kurang dari lima $\operatorname{tahun}^{14}$. Prevalensi gizi kurang dan gizi buruk mulai meningkat pada usia $6-11$ bulan dan mencapai puncaknya pada usia $12-23$ bulan dan $24-35$ bulan $^{19}$. Proporsi gizi kurang di Indonesia sebesar 
$13,8^{20}$. Jawa Timur memiliki proporsi balita dengan gizi kurang sekitar 14\%. Riset Kesehatan dasar di Indonesia tahun 2018 menyatakan bahwa presentase gizi buruk pada balita usia $0-23$ bulan di Indonesia adalah $3,8 \%$, sedangkan presentase gizi kurang adalah $11,4 \%{ }^{21}$. Berkaitan dengan gizi, Indonesia juga memiliki masalah yang cukup besar dari status gizi, salah satunya stunting ${ }^{21}$. Prevalensi stunting pada baduta pada tahun 2017 berdasarkan Profil Anak Indonesia 2018 sebesar $28 \%{ }^{22}$. Sedangkan, jumlah anak baduta yang memiliki status gizi sangat pendek atau pendek di Indonesia sebesar $29,9 \%{ }^{20}$.

Status gizi pada baduta dapat diketahui melalui pengukuran berat badan per panjang badan. Status gizi anak dapat dijadikan sebagai pedoman pencegahan penyakit yang berisiko pada anak untuk kedepannya. Status gizi kurang pada baduta dapat menyebabkan keterlambatan kemampuan motorik, pertumbuhan otak terhambat, daya tahan tubuh menurun, dan pertumbuhan fisik baduta terhambat ${ }^{23}$. Status gizi baduta perlu diketahui dari awal agar bisa dilakukan pencegahan dan pengendalian pada lingkungan dan faktor risiko yang mempengaruhi status gizi, misalnya konsumsi makanan pendamping baduta.

Pelem merupakan salah satu desa yang berada di Kecamatan Purwosari, Kabupaten Bojonegoro yang terdiri dari tiga dusun yaitu Dusun Pelem, Dusun Klubuk, dan Dusun Dukuhan. Berdasarkan data dari Puskesmas Purwosari tahun 2019 jumlah kasus gizi kurang baduta sebanyak 11 anak dan data dari posyandu Desa Pelem bahwa terdapat 8 baduta $(15,7 \%)$ yang memiliki status kurang gizi sesuai dengan catatan grafik perkembangan anak pada Kartu Menuju Sehat. Gizi kurang merupakan status gizi dari kondisi seseorang yang disebabkan kekurangan karbohidrat, lemak, protein, dan vitamin dalam tubuh $^{24}$. Banyaknya baduta yang mengalami gizi kurang di Desa Pelem diakibatkan beberapa faktor, yaitu kurangnya pengetahuan ibu tentang pemenuhan gizi pada anak dan pola asuh yang baik, kurangnya dukungan dan dorongan dari keluarga dalam pemenuhan gizi pada anak dan dukungan keadaan rumah, serta kurangnya dukungan program gizi dan sanitasi rumah yang kurang memadai. Sanitasi rumah yang kurang memadai di Desa Pelem yaitu sumber air bersih, ketersediaan jamban sehat, dan kepemilikan Saluran Pembuangan Air Limbah (SPAL) yang digunakan serta kurangnya partisipasi masyarakat untuk periksa rutin ke posyandu.

Beberapa hal tersebut dapat diketahui baduta yang memiliki status gizi kurang disebabkan karena faktor ketersediaan jamban sehat, kepemilikan SPAL, dan sumber air bersih di Desa Pelem masih rendah. Belum ada penelitian di Desa Pelem mengenai status gizi disebabkan oleh ketersediaan jamban sehat, kepemilikan SPAL, dan sumber air yang digunakan oleh masyarakat. Oleh karena itu, penelitian ini bertujuan untuk menganalisis hubungan sanitasi dasar berupa ketersediaan sarana dasar meliputi sumber air bersih, ketersediaan jamban sehat, dan kepemilikan SPAL terhadap status gizi pada baduta di Desa Pelem.

\section{MATERI DAN METODE}

Penelitian ini merupakan penelitian observasional dengan desain studi cross sectional. Pengambilan data dilakukan pada 28 Desember 2019 - 14 Januari 2020 yang berlokasi di Desa Pelem, Kecamatan Purwosari, Kabupaten Bojonegoro. Populasi penelitian ini adalah seluruh anak yang berusia $0-24$ bulan (baduta) yang berasal dari Desa Pelem. Subjek pada penelitian ini yaitu data anak baduta di Desa Pelem. Jumlah sampel pada penelitian ini merupakan seluruh populasi ibu yang memiliki baduta di Desa Pelem yang berjumlah 60 anak yang tercatat dalam posyandu desa, tetapi karena terdapat informasi yang kurang lengkap dan terdapat keluarga baduta yang sedang ke luar kota sehingga jumlah baduta yang diteliti sebanyak 51 anak.

Metode pengambilan data dengan cara wawancara dan observasi secara langsung menggunakan instrumen lembar observasi dan kuesioner. Observasi yang dilakukan pada penelitian ini yaitu kondisi sanitasi dasar rumah yang meliputi ketersediaan jamban sehat, jenis jamban, ketersediaan septik tank, ketersediaan SPAL, kondisi lantai rumah, kondisi dinding rumah, ketersedian TPS dan tempat sampah. Wawancara dilakukan peneliti menggunakan lembar kuesioner terhadap ibu yang memiliki baduta. Pertanyaan pada lembar kuesioner meliputi sumber air bersih yang digunakan, partisipasi ibu membawa baduta ke posyandu, asupan gizi anak, dan kesehatan anak.

Variabel sumber air bersih, ketersediaan jamban sehat, dan kepemilikan SPAL diukur melalui lembar observasi dan kuesioner yang dijadikan sebagai variabel independent. Variabel sumber air bersih dikategorikan sesuai dengan sumber air yang digunakan oleh masyarakat secara umum. Sedangkan variabel jamban sehat dan SPAL berdasarkan keberadaan variabel tersebut pada setiap rumah. Variabel status gizi atau variabel dependent diukur berdasarkan Kartu Menuju Sehat (KMS) yang berisi mengenai berat badan (BB), panjang badan (PB), dan usia (U) dan diperoleh melalui wawancara pada ibu baduta yang hasilnya ditentukan menjadi dua kategori yaitu status gizi normal dan status gizi kurang. Status gizi baduta diklasifikasikan berdasarkan Peraturan Menteri Kesehatan Republik Indonesia Nomor 2 tahun 2020 tentang standar antropometri anak. Analisis univariat dilakukan pada variabel independent untuk mengetahui frekuensi dan persentase, sedangkan analisis bivariat yang dilakukan menggunakan tabulasi silang dengan uji chi-square, tingkat kepercayaan $\alpha<0,05$ antara variabel sumber air bersih, ketersediaan jamban sehat, dan kepemilikan SPAL dengan status gizi baduta. Hasil uji berupa $p$-value yang mana jika $p$-value $<0,05$ berarti terdapat hubungan terhadap status gizi kurang pada anak usia $0-24$ bulan di Desa Pelem dan jika $p$ - 
value $>0,05$ berarti tidak terdapat hubungan terhadap status gizi pada baduta di Desa Pelem.

Penelitian ini telah diuji kelaikan etik dengan nomor etik 1769-KEPK dan mendapat persetujuan dari pihak penguji di Fakultas Kesehatan Masyarakat Universitas Airlangga. Data yang telah didapatkan akan diolah dan disajikan dalam bentuk tabel dengan penjelasan secara narasi.

\section{HASIL DAN PEMBAHASAN}

Desa Pelem merupakan desa paling selatan di Kecamatan Purwosari. Akses masyarakat dari Desa Pelem menuju ke pelayanan kesehatan tingkat I dan kota jauh. Kondisi masyarakat di Desa Pelem memiliki kader posyandu yang aktif dan mayoritas tingkat pendidikan masyarakat rendah. Hasil penelitian pada 51 baduta di Desa Pelem, Kecamatan Purwosari Bojonegoro menunjukkan bahwa sebanyak $15,7 \%$ dari total baduta di Desa Pelem memiliki status gizi kurang berdasarkan pengukuran berat badan dan panjang badan yang sesuai dengan pedoman berdasarkan Peraturan Menteri Kesehatan Republik Indonesia Nomor 2 tahun 2020. Baduta yang memiliki status gizi kurang harus segera diatasi agar tidak menjadi kekurangan gizi kronis atau stunting.

Tabel 1. Distribusi Karakteristik Baduta Menurut Umur dan Jenis Kelamin di Desa Pelem tahun 2020

\begin{tabular}{lcc}
\hline Karakteristik Baduta & f & \% \\
\hline Umur & & \\
0-11 bulan & 29 & 56,8 \\
12-24 bulan & 22 & 43,2 \\
\hline Jenis Kelamin & & \\
Laki-Laki & 23 & 45,1 \\
$\quad$ Perempuan & 28 & 54,9 \\
\hline Sumber: Data Primer & &
\end{tabular}

Berdasarkan Tabel 1 di atas menunjukkan hasil distribusi terhadap karakteristik baduta menurut umur dan jenis kelamin di Desa Pelem. Kelompok baduta yang berusia $0-11$ bulan merupakan kelompok terbanyak yaitu 56,8\%. Umur baduta di Desa Pelem rata-rata berumur 10 bulan. Jenis kelamin baduta Desa Pelem lebih banyak yang berjenis kelamin perempuan $(54,9 \%)$ dibandingkan baduta yang memiliki jenis kelamin laki-laki $(45,1 \%)$.

Tabel 2. Distribusi Status Gizi Baduta di Desa Pelem tahun 2020

\begin{tabular}{lcc}
\hline Status Gizi & f & \% \\
\hline Normal & 43 & 84,3 \\
Gizi Kurang & 8 & 15,7 \\
\hline Total & 51 & 100 \\
\hline
\end{tabular}

Penentuan status gizi baduta dilakukan dengan melihat kartu menuju sehat atau menghitung berat badan (BB) per tinggi badan (TB) sesuai Permenkes Nomor 2 tahun 2020 tentang standar antropometri anak. Kalkulasi berat badan dan panjang atau tinggi badan baduta didapatkan dari hasil baduta datang ke posyandu untuk melakukan pemerikasaan rutin. Berdasarkan hasil penentuan status gizi baduta di Desa Pelem. Terdapat 8 baduta $(15,7 \%)$ dari 51 baduta yang memiliki status gizi kurang berdasarkan indeks BB/PB, seperti pada tabel 2. Orang tua baduta Desa Pelem 96\% telah memberikan ASI kepada anak mereka sejak awal kelahiran.

Tabel 3. Hasil Analisis Statistik Hubungan Sumber Air Bersih, Ketersediaan Jamban Sehat dan Kepemilikan SPAL di Desa Pelem Tahun 2020

\begin{tabular}{|c|c|c|c|c|c|}
\hline \multirow{2}{*}{ Variabel } & \multirow{2}{*}{$\mathbf{f}$} & \multirow{2}{*}{$\%$} & \multicolumn{2}{|c|}{ Status Gizi (n) } & \multirow{2}{*}{ p-value } \\
\hline & & & Kurang & Normal & \\
\hline \multicolumn{6}{|l|}{ Sumber Air Bersih } \\
\hline Sumur (air tanah) & 48 & 94 & 7 & 41 & \multirow{4}{*}{0,407} \\
\hline Sungai & 1 & 2 & 1 & 0 & \\
\hline PDAM & 0 & 0 & 0 & 0 & \\
\hline Lainnya & 2 & 4 & 0 & 2 & \\
\hline \multicolumn{6}{|c|}{ Ketersediaan Jamban Sehat } \\
\hline $\mathrm{Ya}$ & 31 & 60,7 & 1 & 30 & \multirow[t]{2}{*}{$0,004 *$} \\
\hline Tidak Ada & 20 & 39,3 & 7 & 13 & \\
\hline \multicolumn{6}{|l|}{ Kepemilikan SPAL } \\
\hline $\mathrm{Ya}$ & 21 & 41,2 & 0 & 21 & \multirow[t]{2}{*}{$0,015^{*}$} \\
\hline Tidak & 30 & 58,8 & 8 & 22 & \\
\hline
\end{tabular}

Sumber: Data Primer

Ket: *(signifikan) 
Tabel 3 menunjukkan hasil distribusi frekuensi tiga variabel sanitasi lingkungan baduta yaitu sumber air bersih, ketersediaan jamban sehat, dan kepemilikan saluran pembuangan air limbah (SPAL). Mayoritas sebanyak 94\% keluarga baduta menggunakan air sumur atau air tanah sebagai sumber untuk keperluan sehari-hari seperti mencuci, membersihkan peralatan dapur, dan lain sebagainya. Beberapa keluarga baduta Desa Pelem menggunakan sungai ataupun lainnya, seperti hujan, sebagai sumber air bersih keperluan sehari-hari. Dari 94,0\% baduta, terdapat 7 keluarga baduta yang menggunakan sumur sebagai sumber air bersih yang memiliki status gizi kurang. Keluarga baduta Desa Pelem yang belum memiliki jamban yang memenuhi syarat kesehatan sebesar 39,3\%. 35\% keluarga baduta Desa Pelem yang telah memiliki jamban sehat, ternyata belum seluruhnya mempunyai SPAL atau Saluran Pembuangan Air Limbah. Hanya 41,2\% diantaranya telah memiliki SPAL, kondisi SPAL yang mereka miliki merupakan SPAL terbuka. Seluruh baduta yang berstatus gizi kurangadalah dari keluarga yang tidak memiliki SPAL.

Air bersih, jamban yang sehat, dan ketersediaan SPAL merupakan salah satu bagian dari sanitasi lingkungan. Sanitasi lingkungan merupakan salah satu faktor yang secara tidak langsung dapat mempengaruhi status gizi anak usia $0-24$ bulan. Hasil analisis bivariat pada tabel 2 melalui uji chi square terhadap sanitasi lingkungan dengan status gizi anak menunjukkan bahwa hanya dua variabel sanitasi lingkungan, yaitu ketersediaan jamban sehat (pvalue $=0,004)$ dan kepemilikan SPAL (pvalue $=0,015$ ) yang memiliki hubungan dengan status gizi baduta Desa Pelem. Sedangkan, sumber air bersih (pvalue $=0,407)$ menunjukkan bahwa tidak ada hubungan yang signifikan dengan status gizi baduta Desa Pelem. Sumber air bersih memiliki pvalue yang $>0,05$ sehingga menunjukkan bahwa tidak ada hubungan terhadap status gizi baduta. Ketersediaan jamban sehat dan kepemilikan SPAL menunjukkan terdapat hubungan status gizi kurang baduta dengan $p$ value $<0,05$. Sehingga, ketersediaan jamban sehat dan kepemilikan SPAL merupakan faktor risiko status gizi pada baduta.

\section{Hubungan Sumber Air Bersih Dengan Status Gizi Baduta}

Air merupakan sumber kemakmuran, sumber kehidupan, dan mata pencaharian dalam berbagai aspek, seperti industri, pertanian, transportasi, dan sebagainya $^{25}$. Air juga berperan penting untuk kelangsungan hidup seluruh makhluk hidup ${ }^{26}$. Kehidupan manusia dan ekosistem sangat bergantung pada ketersediaan air dan kualitas yang sesuai ${ }^{27,28}$.

Berdasarkan hasil uji chi-square sumber air bersih terhadap status gizi baduta menunjukkan pvalue $=0,407$, sehingga terbukti bahwa tidak ada hubungan yang siginifikan sumber air bersih dengan status gizi baduta. Seluruh masyarakat Desa Pelem telah mendapatkan akses air bersih dan sumber air bersih yang digunakan masyarakat Desa Pelem mayoritas berasal dari sumur. Penyebab dari pemakaian sumber air bersih dari sumur adalah masih belum banyak masyarakat yang mengenal PDAM. Sumber air di Desa Pelem dapat dikatakan aman karena memiliki berupa sumur ataupun memiliki akses yang disalurkan ke tempat tinggal ${ }^{29}$. Hal tersebut sejalan dengan penelitian Li, etc (2020) bahwa sumber air bersih tidak memiliki hubungan dengan terhadap berat badan dan status gizi anak. Peningkatan kualitas sanitasi lebih terasa manfaatnya dibandingkan peningkatan kualitas sumber air $^{30}$. Sehingga, perubahan sumber air tidak berpengaruh terhadap status gizi baduta jika sanitasi lingkungan rumah masih buruk. Berbanding terbalik dengan penelitian Masnah dan Saputri menyatakan bahwa sarana air bersih memiliki hubungan dengan status gizi kurang pada balita (pvalue $=0,037)^{31}$. Penelitian Ramdaniati dan Nastiti (2019) mengemukakan bahwa sumber air bersih memiliki hubungan dengan kejadian stunting pada balita $(\text { pvalue }=0,011)^{7}$.

Sumber air bersih dari sumur akan aman digunakan jika sumur memiliki tutup, berjarak jauh dari sumber pencemar, serta kondisi dinding sumur baik. Sarana air bersih dari sumur yang tidak tertutup, dinding sumur tidak baik, dan jarak sumur dengan sumber pencemar kurang dari 10 meter akan berpotensi menimbulkan pencemaran pada air ${ }^{8}$. Sumber air bersih dari sungai akan lebih berisiko karena terdapat beberapa masyarakat masih buang air besar sembarangan di sungai. Air bersih memiliki risiko terhadap kontaminasi bakteri, sehingga dapat memicu penyakit lain seperti gastroenteritis karena air berih sering digunakan untuk keperluan mencuci peralatan makan dan peralatan dapur, mencuci pakaian, sikat gigi, dsb. Air sumur dapat dijadikan sebagai kebutuhan air yang umumnya harus melalui pengolahan, seperti dimasak terlebih dahulu. Sanitasi lingkungan yang buruk termasuk air bersih menjadi salah satu faktor risiko terjadinya status gizi pada anak karena anak akan mudah terkena penyakit infeksi ${ }^{32}$.

Penelitian Ramdaniati dan Nastiti menunjukkan bahwa balita yang terkena stunting memiliki hubungan yang signifikan terhadap sumber air (pvalue $=0,011)^{7}$. Nilai determinasi yang dimiliki antara status gizi dengan lingkungan lemah walaupun terdapat hubungan yang signifikan ${ }^{33}$. Tetapi, jika masyarakat menggunakan sumber air yang digunakan masyarakat layak untuk digunakan maka risiko anak terkena masalah gizi akan berkurang. Air yang tidak aman, tidak dapat digunakan untuk mencuci pakaian dan wadah penyimpanan, mencuci tangan, hingga untuk minum karena mengandung bakteri E.coli berbahaya sehingga dapat menyebabkan diare, penurunan nutrisi, hingga infeksi saluran pencernaan $^{34}$. Sumber air bersih yang letaknya berdekatan dengan pembuangan air limbah dan jamban akan memiliki risiko pencemaran yang tinggi, 
sehingga perlu diberikan edukasi untuk memperhatikan jarak antara jamban dan pembuangan air limbah terhadap sumber air yang digunakan ${ }^{35}$. Sumber air yang buruk juga akan meningkatkan risiko stunting pada baduta dan meningkatkan angka putus sekolah $^{36}$.

\section{Hubungan Ketersediaan Jamban Sehat Dengan Status Gizi Baduta}

Ketersediaan jamban memiliki manfaat untuk membuang kotoran anggota keluarga dan baduta. Peningkatan sanitasi jamban yang lebih baik akan memisahkan feses secara higenis dari kontak manusia. Berdasarkan hasil uji chi-square ketersediaan jamban sehat dengan status gizi pada baduta menunjukkan bahwa terdapat hubungan yang signifikan (pvalue= 0,004). Penelitian Hasan dan Kadarusman (2019) dan Yuniar et al (2020) menyatakan bahwa jamban sehat memiliki hubungan dengan status gizi ${ }^{8,37}$. Hal ini berbanding terbalik dengan hasil penelitian serupa di Kabupaten Bondowoso bahwa tidak ada hubungan antara kepemilikan jamban dengan kejadian stunting $^{38}$. Hasil penelitian yang dilakukan oleh Masnah dan Saputri juga menunjukkan bahwa tidak terdapat hubungan antara kondisi jamban dengan status gizi ${ }^{31}$.

Berdasarkan hasil observasi menunjukkan bahwa masih terdapat beberapa rumah yang memiliki jamban yang kurang sehat, tidak tersedia sabun, lantai jamban kotor, serta kebersihan WC masih kurang. Jamban yang tidak memenuhi standar akan memicu timbulnya penyakit infeksi seperti kecacingan dan diare karena hygiene dan sanitasi yang buruk dan dapat menganggu penyerapan nutrisi. Jamban yang tidak sehat akan mudah menularkan infeksi penyakit melalui fecal-oral dari berbagai media langsung, seperti tanah, air atau vektor yang membawa kotoran $^{39}$. Penyerapan nutrisi yang terganggu dapat menyebabkan berat badan baduta turun ${ }^{40}$. Oleh karena itu, penting untuk memperhatikan ketersediaan jamban di setiap rumah dan jamban yang memenuhi persyaratan kesehatan.

Sebuah jamban yang baik memiliki lubang penampung atau biasa disebut septic tank dan model jamban yang tertutup. Masyarakat Desa Pelem yang memiliki jamban sudah disertai dengan septic tank. Septic tank terdiri dari tangki yang kedap air sebagai tempat untuk air buangan dan tempat penampungan feses $^{41}$. Didalam tangki septic tank terjadi proses secara kimiawi untuk memungkinkan bakteri tumbuh subur dan proses secara biologi untuk proses penguraian oleh aktifitas bakteri ${ }^{41}$. Septic tank yang tidak pernah disedot secara rutin dapat menyebabkan kualitas jamban menjadi tidak saniter ${ }^{42}$. Risiko kontaminasi air akan terjadi jika masyarakat memiliki jamban yang tidak tertutup dan septic tank yang tidak tersedia $^{39}$.

Jamban sehat yang telah dimiliki masyarakat Desa Pelem merupakan jamban dengan model leher angsa yang mana jamban jenis ini dapat menjaga lingkungan tetap bersih dan tidak menimbulkan bau disekitarnya. Jamban model leher angsa telah dilengkapi unit penampungan feses dan air untuk mencegah agar tidak ada rodent yang masuk. Jamban jenis cemplung atau tempat pembuangan tinja langsung memiliki risiko tujuh kali lebih besar terinfeksi parasit pada usus dibandingkan dengan jamban leher angsa ${ }^{34}$. Infeksi parasit yang terjadi pada usus secara berulang akan membatasi penyerapan nutrisi dan kalori sehingga mengakibatkan dapat kekurangan gizi ${ }^{34,43,44}$. Penelitian Ramdaniati dan Nastiti yang menunjukkan terdapat hubungan siginifikan antara ketersediaan jamban sehat dengan kejadian stunting ${ }^{7}$. Keberadaan jamban merupakan salah satu faktor yang cukup penting pada status gizi anak dan dapat menjadi salah satu pencegahan penyakit. Anak yang tinggal di rumah tangga yang memiliki jamban sehat dan bersih memiliki kemungkinan rendah terhadap kekurangan gizi (pvalue $<0,001)^{34}$. Maka dari itu, penting bagi setiap keluarga memiliki jamban untuk menjaga kesehatan keluarganya.

Keberadaan jamban yang berjarak dekat dengan sumber air bersih dapat mencemari sumber air bersih karena secara tidak langsung kotoran akan tercampur dengan air. Serta, kondisi jamban yang tidak memenuhi syarat dapat berpotensi mencemari air bersih yang dapat mempengaruhi status gizi anak. Sarana pembuangan feses atau jamban sehat yang memenuhi syarat bangunan Peraturan Menteri Kesehatan Nomor 3 Tahun 2014 merupakan langkah efektif dalam memutus rantai penyebaran penyakit 38,45 .

\section{Hubungan Kepemilikan Saluran Pembuangan Air Limbah (SPAL) Dengan Status Gizi Baduta}

Berdasarkan hasil uji chi-square kepemilikan SPAL terhadap status gizi baduta menunjukkan bahwa ada hubungan yang signifikan (pvalue=0,015). Masyarakat Desa Pelem mayoritas akan mengalirkan air limbahnya (contoh, limbah setelah mencuci baju, mandi, dan lainnya) langsung ke tanah atau perkarangan belakang rumah. Air limbah merupakan air buangan yang tidak mengandung kotoran atau tinja manusia yang berasal dari buangan cuci pakaian, aktivitas dapur, kamar mandi, dan lain-lain. Air limbah mengandung mikroorganisme pathogen yang dapat membahayakan kesehatan manusia ${ }^{46}$. Seluruh SPAL yang dimiliki oleh masyarakat Desa Pelem tidak berbau dan tidak mengalir, sehingga hal tersebut akan memperburuk kualitas badan air. Maka dari itu, setiap rumah tangga perlu memiliki SPAL yang aman sesuai dengan kriteria.

Kriteria umum SPAL yang aman yaitu terbuat dari bahan yang tahan air, tidak menjadi tempat perkembangbiakan vektor, tidak menyebabkan genangan air, tidak berbau, terhubung ke got atau sumur rekasi, dan tertutup ${ }^{45}$. Kondisi SPAL yang terbuka akan berpotensi menjadi tempat perkembangbiakan vektor dan rodent. Saluran air 
limbah yang terbuka akan menimbulkan genangan dan bau karena langsung mengalir ke tanah, sehingga akan langsung mencemari tanah dan air $^{47}$.

Kualitas SPAL yang kurang baik akan mengontaminasi sumur, karena air akan menyerap kedalam tanah atau terbawa ke air sungai sehingga air akan tercemar dan menimbulkan infeksi penyakit menular. Air yang berasal dari bekas cucian dapur, pakaian, kamar mandi merupakan air limbah rumah tangga yang harus dikelola. Keberadaan SPAL merupakan salah satu bentuk pengelolaan air limbah. Air limbah dapat menjadi sarang serangga atau vector penyakit, tempat tinggal bibit penyakit, serta dapat mencemari air tanah ${ }^{48,49}$. Manajemen air limbah yang kurang bagus memiliki hubungan terhadap permasalahan stunting pada anak ${ }^{47,50}$. Soerachmad, dkk (2019) menampilkan hasil bahwa pembuangan air limbah yang tidak aman memiliki pengaruh terhadap kejadian stunting pada anak (pvalue $=0,000)^{9}$.

Manajemen air limbah yang kurang baik bisa menjadi sumber transmisi terjadinya penyakit menular, sehingga akan menganggu pertumbuhan dan perkembangan anak ${ }^{51}$. Penelitian Riogilang menyatakan bahwa saluran drainase air limbah yang baik dan memenuhi syarat dapat menjadikan lingkungan sekitar rmenjadi lebih sehat, mencegah banjir, dan berkurangnya sumber penyakit dari sampah yang menyumbat jalannya air $^{52}$. Pembuangan limbah, baik limbah padat maupun cair, dari rumah tangga harus diolah dengan baik agar tidak mencemari permukaan tanah dan sumber air ${ }^{53}$. Hasil dari penelitian sebelumnya menyatakan bahwa tidak ada hubungan yang signifikan antara ketersediaan SPAL dengan status gizi pada anak (pvalue $=0,879)^{54}$. Beberapa penelitian menyatakan SPAL yang buruk akan lebih mempengaruhi dan memiliki risiko lebih besar terhadap kejadian stunting pada anak ${ }^{9,54}$. Berbanding terbalik dengan hasil statistik yang telah dilakukan, bahwa tidak ada hubungan antara keadaan SPAL yang tertutup dengan status gizi pada anak baduta.

\section{SIMPULAN}

Penelitian terhadap faktor risiko keterssediaan sanitasi dasar dengan status gizi baduta menunjukkan bahwa sanitasi dasar merupakan salah faktor yang tidak langsung mempengaruhi status gizi pada baduta terutama ketersediaan jamban dan SPAL. Sehingga penting untuk selalu menjaga sanitasi dasar lingkungan tetap sehat agar perkembangan dan pertumbuhan baduta baik. Ketersediaan jamban dan SPAL perlu untuk ditingkatkan serta edukasi mengenai jenis jamban yang sehat dan pentingnya SPAL bagi setiap rumah.

Pemerintah Desa Pelem dapat bekerjasama dengan puskesmas Purwosari dan ibu kader untuk melakukan sosialisasi mengenai penyediaan jamban yang sehat dan SPAL yang hygiene. Puskesmas, Polindes, Bidan Desa, dan Kader diharapkan saling bekerja sama untuk melaksanakan program promosi kesehatan dalam meningkatkan pemahaman kesehatan pada masyarakat.

\section{DAFTAR PUSTAKA}

1 Kementerian Kesehatan RI. Kemenkes Tingkatkan Status Gizi Masyarakat. Kementeri. Kesehat. Republik Indones. 2019.https://www.kemkes.go.id/article/view/190 81600004/kemenkes-tingkatkan-status-gizimasyarakat.html (diakses 29 Mar2021).

2 Wahhab. Apa 1000 HPK itu? DPPKBPMD Kabupaten Bantul. 2020.

3 Irianti B. Faktor-Faktor Yang Menyebabkan Status Gizi Kurang Pada Balita di Wilayah Kerja Puskesmas Sail Pekanbaru Tahun 2016. Midwifery J 2018; 3: 95-98. https://doi.org/10.31764/mj.v3i2.478

4 Kementerian Kesehatan RI. Pedoman Pelaksanaan Stimulasi, Deteksi, dan Intervensi Tumbuh Kembang Anak. Kementerian Kesehatan RI, 2016.

5 Simbolon R. Hubungan Faktor Sosial Ekonomi dan Higiene Sanitasi Lingkungan dengan Status Gizi Anak Balita di Desa Nifuboke Tahun 2016. Indones Heal Inf Manag J 2017; 5: 96-102.

6 Riski H, Mundiastutik L, Adi AC. Ketahanan Pangan Rumah Tangga, Kejadian Sakit dan Sanitasi Lingkungan Berhubungan dengan Status Gizi Balita Usia 1-5 Tahun Di Surabaya. Amerta 2019; $\quad 3$ : 130-134. https://doi.org/10.20473/amnt.v3i3.2019.130134

7 Ramdaniati SN, Nastiti D. Hubungan Karakteristik Balita, Pengetahuan Ibu Dan Sanitasi Terhadap Kejadian Stunting Pada Balita Di Kecamatan Labuan Kabupaten Pandeglang. Hear $J$ Kesehat Masy 2019; 7: 47-54. https://doi.org/10.32832/hearty.v7i2.2877

8 Hasan A, Kadarusman H. Akses ke Sarana Sanitasi Dasar sebagai Faktor Risiko Kejadian Stunting pada Balita Usia 6-59 Bulan. J Kesehat 2019; 10: 413-421. https://doi.org/10.26630/jk.v10i3.1451

9 Soerachmad Y, Ikhtiar M, S AB. Hubungan Sanitasi Lingkungan Rumah Tangga Dengan Kejadian Stunting Pada Anak Balita Di Puskesmas Wonomulyo Kabupaten polewali Mandar Tahun 2019 Relationship of Household Environmental Sanitation with Stunting Occurrence in Toddler Children in Wonomulyo He. J Kesehat Masy 2019; 5: 138-150. https://doi.org/10.35329/jkesmas.v5i2.519

10 World Bank. Indonesia Economic Quartenty. World

Bank. 2016.https://www.worldbank.org/en/country/ind onesia/publication/indonesia-economicquarterly-reports.

11 Alifariki LO. Gizi Anak dan Stunting. Penerbit LeutikaPrio: Yogyakarta, 2020https://books.google.co.id/books?id=e9kZE 
AAAQBAJ.

12 Mshida HA, Kassim N, Mpolya E, Kimanya M. Water, Sanitation, and Hygiene Practices Associated with Nutritional Status of Under-Five Children in Semi-Pastoral Communities Tanzania. Am Soc Trop Med Hyg Water 2018; 98:

$1242-1249$.

https://doi.org/10.4269/ajtmh.17-0399

13 Burton MJ, Rajak SN, Hu VH, Ramadhani A, Habtamu E, Massae P et al. Pathogenesis of Progressive Scarring Trachoma in Ethiopia and Tanzania and Its Implications for Disease Control: Two Cohort Studies. PLoS Negl Trop Dis 2015; 9: e0003763. https://doi.org/10.1371/journal.pntd.0003763

14 WHO. Children: improving survival and wellbeing. World Heal. Organ. 2020.https://www.who.int/en/news-room/factsheets/detail/children-reducing-mortality.

15 Syed S, Yeruva S, Herrmann J, Sailer A, Sadiq $\mathrm{K}$, Iqbal $\mathrm{N}$ et al. Environmental Enteropathy in Undernourished Pakistani Children: Clinical and Histomorphometric Analyses. Am J Trop Med Hyg 2018; $\quad 98:$ 1577-1584. https://doi.org/10.4269/ajtmh.17-0306

16 Syed S, Ali A, Duggan C. Environmental Enteric Dysfunction in Children. $J$ Pediatr Gastroenterol Nutr 2016; 63: 6-14. https://doi.org/10.1097/MPG.000000000000114 7

17 Kamara JK, Galukande M, Maeda F, Luboga S, Renzaho AMN. Understanding the Challenges of Improving Sanitation and Hygiene Outcomes in a Community Based Intervention: A CrossSectional Study in Rural Tanzania. Int J Environ Heal Res Public Heal 2017; 14: 1-16. https://doi.org/10.3390/ijerph14060602

18 WHO. Essential Nutrition Actions: Improving Maternal, Newborn, Infant, and Young Child Health and Nutrition. World Health Organization: Switzerland, 2013.

19 UNICEF. State of World Children: Children in an Urban World. New York, 2012.

20 Riskesdas K. Hasil Utama Riset Kesehata Dasar (RISKESDAS). 2018 doi:10.1088/1751$8113 / 44 / 8 / 085201$.

21 Kementerian Kesehatan RI. Profil Kesehatan Indonesia 2019. Kementerian Kesehatan Republik Indonesia: Jakarta, 2020http://www.kemkes.go.id.

22 Kemenppa RI. Profil Kesehatan Anak Indonesia Tahun 2018. Ilmu Pendidik 2018; 5: 12-21.

23 Morinaga Platinum. Dampak Negatif Kurang Gizi untuk Tumbuh Kembang Si Kecil. Morinaga.

2020.https://morinagaplatinum.com/id/milestone /dampak-negatif-kurang-gizi-untuk-tumbuhkembang-si-kecil (diakses 29 Mar2021).

24 Krisnansari D. Nutrisi dan Gizi Buruk. Mandala Heal 2010; 4: 60-68.
25 Grey D, Sadoff C. Sink or Swim? Water Security for Growth and Development. Water Policy 2007; 9. doi:10.2166/wp.2007.021.

26 Azlan A, Khoo HE, Idris MA, A I, Razman M. Consumption Patterns and Perception on Intake of Drinking Water in Klang Valley, Malaysia. Pakistan $J$ Nutr 2012; 11: 584-590. https://doi.org/10.3923/pjn.2012.584.590

27 Ahmed F, Chamhuri S, Begum R. Water resources in Malaysia: Issues and challenges. $J$ Food, Agric Environ 2014; 12: 1100-1104.

28 Asian Water Development Outlook. Achieving Water security for Asia. Asian Development Bank, Metro Manila. Asian Development Bank: Philippines, 2007http://hdl.handle.net/11540/230.

29 Li Z, Kim R, Vollmer S, Subramanian S V. Factors Associated With Child Stunting, Wasting, and Underweight in 35 Low- and Middle-Income Countries. JAMA Netw open 2020; 3: e203386. https://doi.org/10.1001/jamanetworkopen.2020.3 386

30 UNICEF. Poor Sanitation On Nutrition The Impact Of Background Paper: The Impact of Poor Sanitation on Nutrition. SHARE Research Consortium (London School of Hygiene \& Tropical Medicine) in collaboration with the WASH and Nutrition Sections of UNICEF India: India, 2015https://thousanddays.org/wpcontent/uploads/The-Impact-of-Poor-Sanitationon-Nutrition-1.pdf.

31 Masnah C, M SI. Faktor Risiko Gizi Kurang pada Balita di Puskesmas Paal V Kota Jambi. Ris Inf Kesehat 2020; 9: 107-114. https://doi.org/10.30644/rik.v9i2.451

32 Alamsyah D, Mexitalia M, Margawati A, Hadisaputro S, Setyawan $\mathrm{H}$, Ilmu F et al. Beberapa Faktor Risiko Gizi Kurang dan Gizi Buruk pada Balita 12-59 Bulan (Studi Kasus di Kota Pontianak). $J$ Epidemiol Kesehat Komunitas $\quad 2017 ; \quad 2$ : $1-8$. https://doi.org/10.14710/jekk.v2i1.3994

33 Utami NH, Mubasyiroh R. Masalah Gizi Balita dan Hubungannya Dengan Indeks Pembangunan Kesehatan Masyarakat. J Nutr Food Reasearch 2019; 42: 1-10. https://doi.org/10.22435/pgm.v42i1.2416

34 Shrestha A, Six J, Dahal D, Marks S, Meierhofer R. Association of nutrition, water, sanitation and hygiene practices with children's nutritional status, intestinal parasitic infections and diarrhoea in rural Nepal: a cross-sectional study. BMC Public Health 2020; 20: 1241. https://doi.org/10.1186/s12889-020-09302-3

35 Dangiran HL, Dharmawan Y. Analisis Spasial Kejadian Diare dengan Keberadaan Sumur Gali di Kelurahan Jabungan Kota Semarang. $J$ Kesehat Lingkung Indones 2020; 19: 68. https://doi.org/10.14710/jkli.19.1.68-75 
36 Checkley W, Buckley G, Gilman RH, Assis AMO, Guerrant RL, Morris SS et al. Multicountry analysis of the effects of diarrhoea on childhood stunting. Int $J$ Epidemiol 2008; 37: 816-830. https://doi.org/10.1093/ije/dyn099

37 Yuniar WP, Khomsan A, Dewi M, Ekawidyani KR, Vipta A, Mauludyani R. Hubungan antara Perilaku Gizi dan Perilaku Hidup Bersih dan Sehat (PHBS) dengan Status Gizi Baduta Di Kabupaten Cirebon. Amerta 2020; 4: 155-164. https://doi.org/10.20473/amnt.v4i2.2020.155164

38 Sinatrya AK, Muniroh L. Hubungan Faktor Water, Sanitation, and Hygiene (WASH) dengan Stunting di Wilayah Kerja Puskesmas Kotakulon, Kabupaten Bondowoso. Amerta 2019; $\quad 3: \quad 164-170$. https://doi.org/10.20473/amnt.v3i3.2019.164170

39 Kurniawati DP, Arini SY, Awwalina I, Pramesti NA. Poor basic sanitation impact on diarrhea cases in toddlers. $J$ Kesehat Lingkung 2021; 13: 41-47.

https://doi.org/10.20473/jkl.v13i1.2021.41-47

40 Kementerian Kesehatan RI. Buletin Jendela Data dan Informasi Kesehatan: Situasi Balita Pendek (Stunting) di Indonesia. 2018https://pusdatin.kemkes.go.id/folder/view/0 1/structure-publikasi-pusdatin-buletin.html (diakses 28 Feb2021).

41 Rohmah N, Syahrul F. Relationship Between Hand-washing Habit and Toilet Use with Diarrhea Incidence in Children Under. $J$ Berk Epidemiol 2016; 5: 95-106. https://doi.org/10.20473/jbe.V5I12017.95-106

42 Ihsan A, Riviwanto $\mathrm{M}$, Darwel. Pengaruh Sumber Air Bersih, Jamban, dan Pola Asuh Terhadap Stunting Pada Balita Dengan Diare Sebagai Variabel Intervening. Bul Kesehat Lingkung Masy 2020; 39: 1-5. https://doi.org/10.31983/keslingmas.v39i1.5619

43 Black RE, Allen LH, Bhutta ZA, Caulfield LE, de Onis M, Ezzati M et al. Maternal and child undernutrition: global and regional exposures and health consequences. Lancet (London, England) 2008; 371: 243-260. https://doi.org/10.1016/S0140-6736(07)61690-0

44 Guerrant RL, Oriá RB, Moore SR, Oriá MOB, Lima AAM. Malnutrition as an enteric infectious disease with long-term effects on child development. Nutr Rev 2008; 66: 487-505. https://doi.org/10.1111/j.17534887.2008.00082.x
45 Menteri Kesehatan Republik Indonesia. Peraturan Menteri Kesehatan Republik Indonesia Nonor 3 Tahun 2014 Tentang Sanitasi Total Berbasis Masyarakat. 2014.https://peraturan.bpk.go.id/Home/Details/1 16706/permenkes-no-3-tahun-2014.

46 Nugraheni D. Hubungan Kondisi Fasilitas Sanitasi Dasar Dan Personal Hygiene Dengan Kejadian Diare Di Kecamatan Semarang Utara Kota Semarang. J Kesehat Masy 2012; 1: 922933.

47 Wahid NK, Maria IL, Hidayanty H. Relationship Between Drinking Water Sources, Drinking Water Treatment And Sewage Management With Stunting In Two-Years-Old Children In Mamuju Regency. EAS J Nutr Food Sci 2020; 1873: 204-209.

48 Pertiwi TS, Widayani P. Penggunaan Sistem Informasi Geografis untuk Pemetaan Kerentanan Wilayah Berdasarkan Faktor Risiko Kejadian Diare Pada Balita. J Inf Syst Public Heal 2018; 3: $30-39$

49 Kemenkes RI. Situasi Diare di Indonesia. 2011; 2.

50 S S, Anisah UZ. Analisis Pendekatan Sanitasi Dalam Menangani Stunting (Studi Literatur). J Sulolipu Media Komun Sivitas Akad dan Masyaraka 2020; 20: 303-309. https://doi.org/10.32382/sulolipu.v2i20.1745

51 Hafid F, Djabu U, Udin, Nasrul. Efek Program SBABS Terhadap Pencegahan Stunting Anak Baduta di Kabupaten Banggai dan Sigi. Indones $J \quad$ Hum Nutr 2017; 4: 79-87. https://doi.org/10.21776/ub.ijhn.2017.004.02.2

52 Riogilang $H$. Identifikasi dan Pendampingan Untuk Mengatasi Masalah Sanitasi Pada Pemukiman Kumuh di Kampung Sanger, Sario Manado. J LPPM Bid Sains dan Teknol 2016; 3: 54-63.

53 Menteri Kesehatan Republik Indonesia. Keputusan Menteri Kesehatan Nomor 829 Tahun 1999 Tentang: Persyaratan Kesehatan Perumahan. 1999.

54 Purba IG, Sunarsih E, Trisnaini I, Sitorus RJ. Environmental Sanitation and Incidence of Stunting in Children Aged 12-59 Months. $J$ Kesehat Lingkung 2020; 12. doi:https://doi.org/10.20473/jkl.v12i3.2020.189199. 